\title{
Simultaneous selection in progenies of yellow passion fruit using selection indices
}

\author{
Luciana Domiciano Silva Rosado ${ }^{1}$, Carlos Eduardo Magalhães dos Santos ${ }^{2}$, Claudio Horst Bruckner ${ }^{3}$, \\ Endson Santana Nunes ${ }^{4}$, Cosme Damião Cruz
}

\begin{abstract}
This study aimed to evaluate the efficiency of simultaneous selection (selection indices) using estimated genetic gains in yellow passion fruit and to make a comparison between the methodologies of Mulamba \& Mock and Elston. The study was conducted with $26 \mathrm{sib}$ progenies of yellow passion fruit for intrinsic production characteristics including fruit number, fruit mass, fruit length and diameter, and for the fruit characteristics skin thickness, soluble solids and acidity. Two methodologies were applied: first, in the joint analysis of fruit characteristics and of intrinsic production characteristics in a single phase of selection; and second, in the analysis in two phases, in which priority was given to the intrinsic production characteristics in the first phase, and later, in the second phase, the best fruit characteristics were chosen among the progenies of the first phase. The analysis of variance was applied to the data to detect genetic variability among progenies. The Elston's selection indice was unable to provide distribution of genetic gains consistent with the purposes of the study, as it selected a single progeny of passion fruit. However, the index based on the sum of ranks of Mulamba \& Mock was more suitable, as it provided a balanced distribution of gains, selecting a larger number of progenies. The methodology of selection using indices is advantageous in passion fruit, since it contributes to higher genetic gains for all the traits evaluated, and the selection in a single phase was proved efficient for progeny selection.
\end{abstract}

Key words: Passiflora edulis Sims, multivariate analysis, genetic gains in plant breeding.

\section{RESUMO}

\section{Seleção simultânea por índice de seleção em progênies de maracujazeiro-azedo}

Este trabalho objetivou a verificação da eficiência da seleção simultânea (índices de seleção), por meio dos ganhos genéticos estimados, e pela comparação das metodologias de Mulamba \& Mock e de Elston. O trabalho foi realizado na Universidade Federal de Viçosa, avaliando-se 26 progênies de irmãos germanos de maracujazeiro-azedo, para as características intrínsecas da produção, tais como: número de frutos, peso do fruto, comprimento e diâmetro do fruto; e para as características do fruto, como: espessura de casca, teor de sólidos solúveis e acidez. As duas metodologias foram aplicadas, primeiro, na análise conjunta das características do fruto e das características intrínsecas da produção, em um único momento de seleção, e, segundo, na análise em dois momentos, na qual priorizaram-se as características intrínsecas da produção, no primeiro momento, e, posteriormente, no segundo momento, escolheram-se, entre as progênies selecionadas do primeiro momento, as melhores para características do fruto. Os dados foram submetidos à análise de variância, a fim de se verificar a existência de variabilidade genética entre as progênies. Verificou-se que a

Recebido para publicação em 15/03/2010 e aprovado em 30/12/2011

${ }^{1}$ Agronomyst Engineer, Magister Science. Student of the post-graduation program in Plant Breeding, Departamento de Fitotecnia, Universidade Federal de Viçosa. Av. Peter Henry Rolfs, s/n, 36570.000, Viçosa, MG, Brazil. luciana.rosado@ufv.br

${ }_{2}^{2}$ Agronomyst Engineer, Doctor Science. Universidade Federal de Viçosa, Campus de Rio Paranaíba, Rodovia MG-230, km 7, Caixa Postal 22, 38810-000, Rio Paranaíba, MG, Brazil. carlos.magalhaes@ufv.br

${ }^{3}$ Agronomyst Engineer, Doctor Science. Departamento de Fitotecnia, Universidade Federal de Viçosa. Av. Peter Henry Rolfs, s/n, 36570.000, Viçosa, MG, Brazil. bruckner@ ufv.br ${ }^{4}$ Agronomyst Engineer, Doctor Science. CanaVialis S.A., Rua James Clerk Maxwell, 320, 13069-380, Campinas, SP, Brazil. endson.s.nunes@canavialis.com.br

${ }_{5}^{5}$ Agronomyst Engineer, Doctor Science. Departamento de Biologia Vegetal, Universidade Federal de Viçosa. Av. Peter Henry Rolfs, s/n, 36570.000, Viçosa, MG, Brazil. cdcruz@ ufv.br 
utilização do índice de seleção de Elston não foi capaz de proporcionar distribuição de ganhos, condizentes com os propósitos do trabalho, ao selecionar uma única progênie de maracujazeiro. O índice baseado na soma de 'ranks' de Mulamba \& Mock revelou-se mais adequado, pois promoveu distribuição de ganhos equilibrada, selecionando maior número de progênies. A metodologia de seleção por índices é vantajosa em maracujazeiro, uma vez que contribui para maiores ganhos totais para os caracteres avaliados, sendo que a estratégia de seleção em um único momento revelouse eficiente na seleção das progênies.

Palavras-chave: Passiflora edulis Sims, análise multivariada, ganhos genéticos, melhoramento vegetal.

\section{INTRODUCTION}

In recent years the area under passion fruit (Passiflora edulis Sims) cultivation has been expanding to meet the demand of the market for fresh fruit. However, although Brazil is the world's largest producer of passion fruit, the average yield per area is $14.15 \mathrm{t} \mathrm{ha}^{-1}$ year (IBGE, 2010), considered well below the potential of which the crop is capable. This low yield has been attributed to the limited number of improved varieties and the low technology of cultivation used by farmers.

Passion fruit breeding programs aim at improving morphological, physiological and agronomic traits that promote increased productivity, improved fruit quality and search for genotypes resistant or tolerant to important pests and diseases, as well as with greater stability of production (Gonçalves et al., 2007, Pimentel et al., 2008, Santos et al., 2010, Santos et al., 2011).

Several breeding methods are applicable to passion fruit, aiming to increase the frequency of favorable alleles or exploitation of hybrid vigor (Meletti et al., 2000). Thus, it is possible to obtain improved populations for several traits of interest and still maintain the allelic variability in the self-incompatibility loci (Suassuna et al., 2003).

Attaining selection for complex traits is especially difficult, such as obtaining a genotype with acceptable averages for several traits, therefore, methods are needed to facilitate the selection. Selection indices were developed to enable the simultaneous selection of traits; a technique that allows the objective application of simultaneous selection of a number of agronomically important traits (Vilarinho et al., 2003).

For this reason, Smith (1936) proposed the theory of the selection index, which is widely used in plant breeding. This technique has been undergoing changes, evaluations and comparisons with other methods of selection so as to ensure greater reliability of the results (Martins et al., 2006, Gonçalves et al., 2007, Santos et al., 2008).

There are some difficulties and limitations in using selection indices, however, they provide valuable selection gains, adequately distributed among the traits, meeting the purposes of breeding. It is important, thus, to identify the selection criteria that promote changes in the desired direction and in the characteristics of interest of a breeding program (Reis et al., 2004).

Cruz et al. (1993) found positive results using the indices of Mulamba \& Mock (1978), Elston (1963) and Williams (1962) in full-sib progenies of maize.

Paiva et al. (2002) verified the efficiency of the methodology of Mulamba \& Mock (1978) in the selection of Barbados cherry (Malpighia punicifolia L.) progenies, in comparison with the traditional method of selection among progenies and within progeny. Similar results were reported by Santos et al., (2008), who found a slight superiority of this methodology in the selection of passion fruit progenies for scab incidence as compared with the index of Pesek \& Baker.

There are superior genotypes of passion fruit selected by simultaneous selection based on the intrinsic production characteristics, such as fruit number and fruit size, when compared with the same method of selection based on the fruit characteristics, such as skin thickness, soluble solids and acidity.

In this context, the objective of this study was to promote simultaneous selection (selection indices), in a single phase and in two phases, based on the characteristics evaluated, in 26 sib progenies of yellow passion fruit.

\section{MATERIALS AND METHODS}

Twenty-six sib progenies of yellow passion fruit (Passiflora edulis) derived from crosses among progenies selected for yield and fruit quality in two commercial fields; one located in the municipality of Jacinto Machado, and the other in the municipality of Guiricema, MG; were evaluated at the experimental field of the Department of Plant Science, Federal University of Viçosa, from October to December 2004.

The plants were arranged in a spacing of $3.0 \mathrm{~m}$ between rows and $3.5 \mathrm{~m}$ between plants, totaling 950 plants/ha in a randomized block design with three replications and four plants per plot. Vines were trained to a single supporting 
wire trellis (1.2 mm diameter) at $1.80 \mathrm{~m}$ high, and all cultivation practices usually recommended for the crop were carried out.

Priority was given to the joint analysis of the characteristics of plants and fruits in a single phase of selection, and then the analyses of plants characteristics were made, ignoring the characteristics related to fruit, and the best plants were selected and analyzed in a second phase for the selection of those with the best characteristics of fruit.

Ten fruits from natural pollination, showing at least $30 \%$ of yellowish skin color, were collected from each plant. The following characteristics were recorded: number of fruits per plant (NF), at the first peak of production in the first year (December 2004); fruit mass (FM), from a digital scale in grams $(\mathrm{g})$; average shell mass (SM), from a digital scale in grams $(\mathrm{g})$; average pulp mass (PM), by subtracting the shell mass from fruit mass ( $\mathrm{PM}=\mathrm{FM}$ $\mathrm{SM}$ ), fruit length (FL), measuring the longitudinal axis of the fruit with a digital caliper in millimeters $(\mathrm{mm})$; average fruit diameter (FD), by measuring the widest equatorial region of the fruit using a digital caliper in millimeters $(\mathrm{mm})$, rind thickness (RT), from the middle portion of sliced fruits using a digital caliper in millimeters $(\mathrm{mm})$, average content of soluble solids (TSS), using a hand digital refractometer with ATC $\left(0-32^{\circ}\right.$ Brix $)$, in an aliquot of juice from each fruit; average titratable acidity (TA), using a digital buret, as grams of citric acid per $100 \mathrm{ml}$ juice.

Using the indices based on the weight-free index or parameters (Elston, 1963) and those based on the rank summation index of Mulamba \& Mock (1978), which ranks the genotypes in relation to each trait, by assigning higher absolute values to those of better performance and, then, the values assigned to each trait are summed, obtaining the sum of the genotype's ranks, which results in an additional score taken as a selection index (Cruz et al., 2004).

Data were subjected to a preliminary analysis of variance to detect genetic variability among progenies. The prediction of gains was made to achieve an ideotype, and the best progenies were selected based on the performance on the fruit number (above 50 fruits/plant), fruit fresh mass (above 200 grams), length (above $80 \mathrm{~mm}$ ), fruit diameter (above $70 \mathrm{~mm}$ ), fresh mass of pulp (above 90 grams), fresh mass of shell (below 110 grams), rind thickness (below $4.0 \mathrm{~mm}$ ), soluble solids (above $11^{\circ}$ Brix) and total titratable acidity (above 2.5 grams of citric acid per $100 \mathrm{ml}$ of juice).

When the indices were applied to all the traits jointly, in a single phase, the selection pressure considered was $20 \%$, resulting in the five best progenies; whereas the selection indices applied in two phases aimed to select $50 \%$ of the progenies in the first phase, resulting in 13 progenies for fruit number, fruit fresh mass, fruit length and fruit diameter; and in the second phase, the selection among the 13 previously selected progenies produced the five best progenies for the other traits, which corresponds to a selection pressure of $38 \%$.

The main objective of using the methodology of selection in a single phase and in two phases was that the amount of progenies at the end of both cycles should correspond to $25 \%$ of the total progenies. The progenies will be recombined to form the population for the next selection cycle. The statistical analyses and simultaneous selection were performed using the software GENES (Cruz, 2006).

\section{RESULTS AND DISCUSSION}

In this work, a greater predicted genetic gain was obtained by using the methodology Mulamba \& Mock, when the selection in a single phase was superior or similar to the selection performed in two different phases, except for the trait fruit mass (FW-Table 1). Five progenies $(5,7,13,17$ and 19) were selected based on the physicochemical characteristics evaluated in the yellow passion fruit, in a single phase. Five progenies (7, 11, 13, 17 and 19) were also listed for the selection in two phases, and the coincidence of three progenies between the strategies allows us to infer the existence of a good relationship between them.

The Weight-Free Index of Elston (1963) provided high selection gains, in a single phase, for fruit number, pulp mass and rind thickness, which appeared with negative gains due to the direction of the selection (Table 2). In contrast, when using the partition of the selection by the Elston's index in two phases, there was higher genetic gain for the fruit number, in the first phase, and rind thickness, in the second phase.

Oliveira et al., (2008) reported greater desired gains for fruit weight, pulp yield, length and width of fruit and larger number of fruit per plant in yellow passion fruit, when using the weight-free index (Elston, 1963). The authors proposed the use of the Elston's index in selecting plants to be recombined and initiate a new selection cycle to create new varieties of passion fruit.

Likewise, Martins et al., (2006) found that the weightfree index of Elston (1963) showed a trend of improvement in traits evaluated in eucalyptus, suggesting that this is due to the building structure of the index, which establishes minimum levels of selection for each trait.

Similar results were reported by Gonçalves et al., (2007), working with prediction of genetic gains for fruit quality in yellow passion fruit based on the selection indices of Smith \& Hazel (SH), Pesek \& Baker and Mulamba $\&$ Mock; they verified that the $\mathrm{SH}$ index produced the 
lowest predicted gain, resulting in poor gains, however, the indices of Mulamba \& Mock and Pesek \& Baker provided greater predicted gains, with a slight superiority for the index of Mulamba \& Mock (1978).

When comparing the genetic gains obtained by the rank summation index of Mulamba \& Mock and the weight-free index of Elston, it was found that for a single phase of selection, the indices showed similar genetic gains, with a slight superiority for the index of Mulamba $\&$ Mock (Tables 1 and 2). However, when the indices are compared in two phases, the genetic gains obtained by the two methodologies were similar; the Elston's index was superior for fruit number and rind thickness, while the index of Mulamba \& Mock was superior for fruit mass and shell mass.

Vasconcelos et al., (2010) found that the highest estimates of genetic gain for productive, morphological and chemical characteristics in superior genotypes of alfalfa were obtained with the indices of Mulamba \& Mock (1978), distance from the ideotype and the Elston's index (1963).

Cruz et al., (1993) and Costa et al., (2004) also found positive results using the indices of Mulamba \& Mock in studies with corn and soybean, respectively.

In this study, the methodology of Mulamba \& Mock selected five progenies $(5,7,13,17$ and 19) in a single phase, while the method proposed by Elston selected only one (19) (Tables 1 and 2). The index of Mulamba \& Mock also selected a greater number of progenies (five) in two phases, while the Elston's index selected less progenies (four), however, the progenies 13,17 and 19 were coincident between the two methodologies.

The difference observed in the selection of genotypes by these two methodologies was also reported by Vasconcelos et al., (2010) when working with selection of progenies of alfalfa.

Similar results, regarding the two methodologies, were also found by Lessa et al., (2010), aiming to select diploid hybrids (AA) of banana using three non-parametric indices; they concluded that the indices of Elston (1963), Mulamba \& Mock (1978) and Schwarzbach (1972, as cited in Wricke \& Weber, 1986) were efficient to rank the diploid banana hybrids, however, the first two indices provided a better ranking.

In intrapopulational breeding programs of popcorn aimed at obtaining higher genetic gains for yield and popping expansion, Vilarinho et al., (2002, 2003), working with selection of inbred progenies S1 and S2, and Santos et al., (2007), working with the selection of half-sib families, found that the index of Mulamba \& Mock provided the best gain estimates.

Table 3 shows the results for the selection in two phases using the Elston's index in the first phase and the index of Mulamba \& Mock in the second phase. The predicted gains in the first phase were similar to those obtained by the Elston's index (Table 2), when using the selection in two phases. However, the genetic gains in the second phase, using the index of Mulamba \& Mock,

Table 1 - Estimates of predicted genetic gains using the rank summation index of Mulamba \& Mock for the selection of progenies in yellow passion fruit in a single phase and in the first and second phases.

\begin{tabular}{|c|c|c|c|}
\hline Selection & Traits & SG \% (Predicted Mean) & Selected Progenies \\
\hline \multirow{9}{*}{ Single Phase } & NF & $18.04(71.20)$ & \multirow{9}{*}{$5,7,13,17$ and 19} \\
\hline & FM & $3.63(228.30)$ & \\
\hline & FL & $5.3(95.92)$ & \\
\hline & FD & $0.86(79.58)$ & \\
\hline & $\mathrm{PM}$ & $5.93(110.33)$ & \\
\hline & SM & $0.54(117.96)$ & \\
\hline & RT & $-3.47(4.39)$ & \\
\hline & TSS & $-3.8(13.09)$ & \\
\hline & TA & $0(2.92)$ & \\
\hline \multirow{4}{*}{$1^{\text {st }}$ Phase } & $\mathrm{NF}$ & $3.37(59.60)$ & \multirow{4}{*}{$2,4,5,6,7,11,13,16,17,18,19,24$ and 26} \\
\hline & FM & $6.43(225.60)$ & \\
\hline & FL & $3.61(94.52)$ & \\
\hline & FD & $0.90(79.96)$ & \\
\hline \multirow{5}{*}{$2^{\text {nd }}$ Phase } & $\mathrm{PM}$ & $0(109.18)$ & \multirow{5}{*}{$7,11,13,17$ and 19} \\
\hline & SM & $-1.65(116.77)$ & \\
\hline & $\mathrm{RT}$ & $-0.16(4.38)$ & \\
\hline & TSS & $-0.13(13.06)$ & \\
\hline & TA & $0(2.91)$ & \\
\hline
\end{tabular}

NF: number of fruits per plant; FM: fruit fresh mass (g); FL: fruit length (mm); FD: fruit diameter (mm); PM: pulp fresh mass (g); SM: shell fresh mass (g); RT: rind thickness (mm); TSS: total soluble solids ( ${ }^{\circ}$ Brix); and TA: total titratable acidity (\% citric acid per 100 ml of juice).

Rev. Ceres, Viçosa, v. 59, n.1, p. 95-101, jan/fev, 2012 
were zero or very close to zero, indicating the nonoccurrence of gains and the similarity of the progenies selected with the methodology in two phases, when using the Elston's index.

Table 4 shows the means ( \pm s.d.) for each trait evaluated for selection of the 26 progenies. Among these progenies, for the set of traits evaluated, the progenies 13, 17 and 19 stand out with means that corresponded to those sought by breeding programs, indicating these progenies as suitable for crosses that will provide a new breeding population.

Studies using selection indices for breeding programs of passion fruit are scarce, although the importance of obtaining efficient methodologies for the selection of progenies with agronomically important traits, maintaining the genetic variability of the population and thus reducing errors that can lead to unsatisfactory results.

Cruz et al., (2004) discuss that selection based on a single trait is inappropriate, because it results in a superior final product with respect to that trait, but may lead to performances not so favorable for the other traits. According to Oliveira et al. (2008), increased success in selection can be achieved by the simultaneous selection of traits, hence the use of selection indices becomes an efficient alternative because it allows the selection based on a number of traits of interest.

Thus, the simultaneous selection of traits in yellow passion fruit, using the index of Mulamba \& Mock, allowed the selection of genotypes that accumulated genetic gains in all traits, even though these gains have been balanced.

Table 2 - Estimates of predicted genetic gains using the weight-free index of Elston in the selection of progenies of yellow passion fruit in a single phase and in the first and second moments.

\begin{tabular}{|c|c|c|c|}
\hline Selection & Traits & SG \% (Predicted Mean) & Selected Progenies \\
\hline \multirow{9}{*}{ Single Phase } & $\mathrm{NF}$ & $17.35(70.52)$ & \multirow{9}{*}{19} \\
\hline & FM & $3.48(227.66)$ & \\
\hline & FL & $3.81(94.30)$ & \\
\hline & FD & $0.36(78.90)$ & \\
\hline & $\mathrm{PM}$ & $8.52(116.60)$ & \\
\hline & SM & $-3.1(111.06)$ & \\
\hline & RT & $-6.78(3.92)$ & \\
\hline & TSS & $-2.45(13.41)$ & \\
\hline & TA & $0(2.93)$ & \\
\hline \multirow{4}{*}{$1^{\text {st }}$ Phase } & $\mathrm{NF}$ & $14.26(67.45)$ & \multirow{4}{*}{$1,2,3,4,5,6,11,12,13,16,17,19$ and 25} \\
\hline & FM & $2.01(221.3)$ & \\
\hline & FL & $3.1(93.53)$ & \\
\hline & FD & $0.56(79.18)$ & \\
\hline \multirow{5}{*}{$2^{\text {nd }}$ Phase } & $\mathrm{PM}$ & $0.14(110.25)$ & \multirow{5}{*}{$3,13,17$ and 19} \\
\hline & SM & $0(114.92)$ & \\
\hline & RT & $-5.05(4.31)$ & \\
\hline & TSS & $-0.14(13.30)$ & \\
\hline & TA & $0(2.98)$ & \\
\hline
\end{tabular}

NF: number of fruits per plant; FM: fruit fresh mass (g); FL: fruit length (mm); FD: fruit diameter (mm); PM: pulp fresh mass (g); SM: shell fresh mass (g); RT: rind thickness (mm); TSS: total soluble solids ( ${ }^{\circ}$ Brix); and TA: total titratable acidity (\% citric acid per 100 ml of juice).

Table 3 - Estimates of predicted genetic gains using the weight-free index of Elston in the first phase and the rank summation index of Mulamba \& Mock in the second phase of selection of progenies of yellow passion fruit.

\begin{tabular}{lccc}
\hline Selection & Traits & SG \% (Predicted Mean) & Selected Progenies \\
\hline \multirow{3}{*}{$1^{\text {st }}$ Phase } & NF & $14.26(67.45)$ & \\
& FM & $2.01(221.3)$ & $1,2,3,4,5,6,11,12,13,16,17,19$ and 25 \\
& FL & $3.1(93.53)$ & \\
FD & $0.56(79.18)$ & $1,3,13,17$ and 19 \\
$2^{\text {nd }}$ Phase & PM & $0.09(107.25)$ & \\
& SM & $0(113.75)$ & \\
& RT & $-0.20(4.38)$ & \\
\hline
\end{tabular}

NF: number of fruits per plant; FM: fruit fresh mass (g); FL: fruit length (mm); FD: fruit diameter (mm); PM: pulp fresh mass (g); SM: shell fresh mass (g); RT: rind thickness (mm); TSS: total soluble solids ( ${ }^{\circ}$ Brix); and TA: total titratable acidity (\% citric acid per 100 ml of juice). 
Table 4 - Means and standard deviation of the physicochemical characteristics of fruits of genotypes of yellow passion fruit

\begin{tabular}{|c|c|c|c|c|c|c|c|c|c|}
\hline GENOTYPE & NF & FM & FL & FD & RT & PM & BRIX & $\mathbf{S M}$ & TA \\
\hline 01 & $46.33 \pm 23.51$ & $204.36 \pm 15.40$ & $85.22 \pm 0.50$ & $78.97 \pm 2.12$ & $4.67 \pm 0.42$ & $95.27 \pm 9.09$ & $14.71 \pm 0.38$ & $109.09 \pm 6.77$ & $2.95 \pm 0.32$ \\
\hline 02 & $94.25 \pm 25.47$ & $218.40 \pm 13.01$ & $94.42 \pm 2.22$ & $80.25 \pm 3.03$ & $5.07 \pm 1.56$ & $100.87 \pm 5.35$ & $12.29 \pm 0.45$ & $120.10 \pm 5.54$ & $2.57 \pm 0.32$ \\
\hline 03 & $47.83 \pm 34.44$ & $223.19 \pm 12.68$ & $91.25 \pm 3.00$ & $78.09 \pm 2.78$ & $4.79 \pm 0.09$ & $105.79 \pm 10.37$ & $13.71 \pm 0.59$ & $117.40 \pm 4.60$ & $3.03 \pm 0.44$ \\
\hline 04 & $47.25 \pm 32.32$ & $230.12 \pm 21.76$ & $93.10 \pm 1.97$ & $82.09 \pm 1.80$ & $5.00 \pm 0.69$ & $96.52 \pm 26.10$ & $14.51 \pm 1.88$ & $133.60 \pm 10.30$ & $2.65 \pm 0.42$ \\
\hline 05 & $84.25 \pm 21.72$ & $229.16 \pm 20.63$ & $100.88 \pm 0.74$ & $80.23 \pm 1.61$ & $4.57 \pm 0.64$ & $106.71 \pm 14.14$ & $12.47 \pm 1.27$ & $122.45 \pm 12.91$ & $2.72 \pm 0.65$ \\
\hline 06 & $56.25 \pm 21.39$ & $219.91 \pm 13.76$ & $93.85 \pm 4.62$ & $77.82 \pm 1.39$ & $4.87 \pm 0.86$ & $102.41 \pm 14.11$ & $13.60 \pm 1.77$ & $121.10 \pm 4.02$ & $2.96 \pm 0.75$ \\
\hline 07 & $35.64 \pm 40.72$ & $234.81 \pm 14.45$ & $95.28 \pm 2.42$ & $81.12 \pm 2.81$ & $4.93 \pm 0.79$ & $109.72 \pm 6.95$ & $13.46 \pm 1.23$ & $125.09 \pm 9.83$ & $2.98 \pm 0.54$ \\
\hline 08 & $37.50 \pm 30.63$ & $204.08 \pm 32.91$ & $84.04 \pm 6.71$ & $77.64 \pm 3.39$ & $4.83 \pm 0.39$ & $90.87 \pm 21.26$ & $14.21 \pm 1.07$ & $113.21 \pm 13.12$ & $2.53 \pm 0.64$ \\
\hline 09 & $29.83 \pm 14.97$ & $218.64 \pm 23.64$ & $90.51 \pm 3.45$ & $77.65 \pm 2.36$ & $5.01 \pm 0.51$ & $95.76 \pm 15.41$ & $14.73 \pm 0.57$ & $122.88 \pm 8.90$ & $2.69 \pm 0.17$ \\
\hline 10 & $41.53 \pm 31.67$ & $179.42 \pm 10.69$ & $81.20 \pm 2.52$ & $73.22 \pm 2.45$ & $4.82 \pm 1.09$ & $86.29 \pm 4.27$ & $13.85 \pm 0.43$ & $93.12 \pm 6.43$ & $3.04 \pm 0.34$ \\
\hline 11 & $96.00 \pm 36.31$ & $217.49 \pm 2.62$ & $95.88 \pm 0.61$ & $79.17 \pm 1.33$ & $4.52 \pm 0.41$ & $100.98 \pm 4.86$ & $12.34 \pm 0.12$ & $116.51 \pm 2.72$ & $2.68 \pm 0.21$ \\
\hline 12 & $55.36 \pm 2.13$ & $214.51 \pm 35.62$ & $91.98 \pm 8.51$ & $76.76 \pm 3.44$ & $5.48 \pm 0.96$ & $95.22 \pm 20.05$ & $13.63 \pm 2.27$ & $119.28 \pm 15.77$ & $3.23 \pm 0.74$ \\
\hline 13 & $118.08 \pm 26.41$ & $221.25 \pm 27.97$ & $94.59 \pm 3.43$ & $77.71 \pm 2.67$ & $4.60 \pm 0.13$ & $105.53 \pm 10.52$ & $12.46 \pm 1.21$ & $115.71 \pm 17.53$ & $2.99 \pm 0.41$ \\
\hline 14 & $34.61 \pm 7.60$ & $222.29 \pm 15.33$ & $90.69 \pm 0.76$ & $79.18 \pm 1.72$ & $5.33 \pm 1.43$ & $97.49 \pm 9.43$ & $16.84 \pm 2.61$ & $124.80 \pm 5.95$ & $2.80 \pm 0.73$ \\
\hline 15 & $40.00 \pm 53.23$ & $191.17 \pm 16.63$ & $83.08 \pm 2.26$ & $74.69 \pm 1.46$ & $5.31 \pm 1.01$ & $84.47 \pm 12.43$ & $14.79 \pm 0.36$ & $106.71 \pm 11.41$ & $3.04 \pm 0.32$ \\
\hline 16 & $58.08 \pm 16.46$ & $227.56 \pm 31.46$ & $95.66 \pm 4.11$ & $79.47 \pm 3.14$ & $5.55 \pm 0.07$ & $96.71 \pm 10.49$ & $12.68 \pm 1.40$ & $130.84 \pm 21.09$ & $2.51 \pm 0.40$ \\
\hline 17 & $47.53 \pm 29.49$ & $228.62 \pm 6.61$ & $94.55 \pm 1.69$ & $79.94 \pm 2.52$ & $3.95 \pm 0.15$ & $113.10 \pm 8.21$ & $13.64 \pm 0.63$ & $115.52 \pm 11.12$ & $2.99 \pm 0.33$ \\
\hline 18 & $42.61 \pm 19.01$ & $226.48 \pm 22.13$ & $92.88 \pm 1.06$ & $80.15 \pm 2.35$ & $4.76 \pm 0.61$ & $104.09 \pm 5.68$ & $13.31 \pm 1.85$ & $122.39 \pm 16.66$ & $2.78 \pm 0.69$ \\
\hline 19 & $70.53 \pm 21.40$ & $227.66 \pm 19.13$ & $94.31 \pm 4.41$ & $78.91 \pm 1.18$ & $3.93 \pm 0.27$ & $116.60 \pm 16.03$ & $13.42 \pm 1.13$ & $111.06 \pm 4.34$ & $2.93 \pm 0.22$ \\
\hline 20 & $30.89 \pm 18.19$ & $190.00 \pm 22.48$ & $82.86 \pm 3.21$ & $79.60 \pm 0.55$ & $5.07 \pm 0.83$ & $82.74 \pm 15.74$ & $15.02 \pm 1.46$ & $107.25 \pm 12.20$ & $2.73 \pm 0.78$ \\
\hline 21 & $63.67 \pm 13.12$ & $172.38 \pm 27.94$ & $80.14 \pm 3.80$ & $74.34 \pm 3.03$ & $5.11 \pm 1.06$ & $74.12 \pm 16.09$ & $15.08 \pm 1.35$ & $98.26 \pm 11.86$ & $2.65 \pm 0.07$ \\
\hline 22 & $53.72 \pm 40.70$ & $186.26 \pm 29.18$ & $82.89 \pm 8.50$ & $75.82 \pm 5.92$ & $5.26 \pm 0.78$ & $80.21 \pm 8.96$ & $14.69 \pm 0.85$ & $106.05 \pm 23.69$ & $2.81 \pm 0.25$ \\
\hline 23 & $75.56 \pm 53.01$ & $174.46 \pm 17.88$ & $81.66 \pm 1.64$ & $73.75 \pm 2.11$ & $4.99 \pm 0.75$ & $77.49 \pm 8.29$ & $14.75 \pm 1.18$ & $96.97 \pm 9.62$ & $2.74 \pm 0.57$ \\
\hline 24 & $10.50 \pm 7.86$ & $228.71 \pm 44.83$ & $91.41 \pm 3.78$ & $80.34 \pm 2.16$ & $5.11 \pm 0.77$ & $91.87 \pm 35.39$ & $15.66 \pm 0.94$ & $136.84 \pm 13.76$ & $3.03 \pm 0.29$ \\
\hline 25 & $55.22 \pm 47.11$ & $214.75 \pm 24.73$ & $90.28 \pm 1.75$ & $79.93 \pm 3.44$ & $4.90 \pm 0.56$ & $92.15 \pm 11.19$ & $14.21 \pm 1.46$ & $122.60 \pm 14.39$ & $2.85 \pm 0.44$ \\
\hline 26 & $13.86 \pm 4.90$ & $223.92 \pm 29.22$ & $92.05 \pm 6.58$ & $82.36 \pm 4.57$ & $4.65 \pm 0.16$ & $92.27 \pm 18.91$ & $14.08 \pm 1.98$ & $131.65 \pm 10.54$ & $2.83 \pm 0.13$ \\
\hline
\end{tabular}

NF: number of fruits per plant; FM: fruit fresh mass (g); FL: fruit length (mm); FD: fruit diameter (mm); PM: pulp fresh mass (g); SM: shell fresh mass (g); RT: rind thickness (mm); TSS: total soluble solids ( ${ }^{\circ}$ Brix); and TA: total titratable acidity (\% citric acid per $100 \mathrm{ml}$ of juice). 
The findings in this study may assist breeding programs of passion fruit, aiming at increasing the efficiency of selection, maximizing selection gains and effectively assisting in selecting progenies to be used in future crosses.

In this case, it is advisable to use the theory of selection indices in an attempt to obtain more balanced gains for the traits considered agronomically superior.

\section{CONCLUSIONS}

The Elston's selection index was unable to provide distribution of gains consistent with the purposes of the study, by selecting only a single progeny of passion fruit.

The rank summation index of Mulamba \& Mock was more suitable under the conditions of this study, providing a balanced distribution of gains by selecting a larger number of progenies.

The use of selection indices in passion fruit was beneficial, because it contributed to greater total gains for the traits evaluated, which is favorable to breeding programs.

The strategy of selection in a single phase proved to be efficient in selecting progenies of passion fruit.

\section{ACKNOWLEDGEMENTS}

The authors thank to the Coordination of Improvement of Higher Education Personnel (CAPES), the National Council for Scientific and Technological Development (CNPq) and Foundation for Research Support of Minas Gerais (FAPEMIG) for granting of scholarships and financial support.

\section{REFERENCES}

Costa MM, Mauro AOD, Unêda-Trevisoli SH, Arriel NHC, Bárbaro IM \& Muniz FRS (2004) Ganho genético por diferentes critérios de seleção em populações segregantes de soja. Pesquisa Agropecuária Brasileira, 39:1095-1102.

Cruz CD, Vencovsky R, Silva SO \& Tosello GA (1993) Comparison of gains from selection among com progênies, based on different criteria. Revista Brasileira de Genética, 16:79-89.

Cruz CD, Regazzi AJ \& Carneiro PCS (2004) Modelos biométricos aplicados ao melhoramento genético. Viçosa, UFV, 480p.

Cruz CD (2006) Programa GENES: Biometria. Viçosa, UFV, 382p.

Elston RC (1963) A weight-free index for the purpose of ranking or selection with respect to several traits at a time. Biometrics, 19:85-97

Gonçalves GM, Viana AP, Barros Neto FV, Pereira MG \& Pereira TNS (2007) Seleção e herdabilidade na predição de ganhos genéticos em maracujá-amarelo. Pesquisa Agropecuária Brasileira, 42:235-240.

IBGE. Instituto Brasileiro de Geografia e Estatística Indicadores: Produção Agrícola Municipal. Disponível em: <http:// www.ibge.gov.br/>. Acessado em: 5 nov. 2010.
Lessa LS, Ledo CAS, Santos VS, Silva S \& Peixoto CP (2010) Seleção de híbridos diplóides (AA) de bananeira com base em três índices não paramétricos. Bragantia, 69:525-534.

Martins IS, Martins RCC \& Pinho DS (2006) Alternativas de índices de seleção em uma população de Eucalyptus grandis Hill ex Maiden. Cerne, 12:287-291.

Meletti LMM, Santos RR \& Minami K (2000) Melhoramento do maracujazeiro-amarelo: obtenção do composto IAC-27. Scientia Agrícola, 57:491-498.

Mulamba NN \& Mock JJ (1978) Improvement of yield potential of the Eto Blanco maize (Zea mays L.) population by breeding for plant traits. Egyptian Journal of Genetics and Cytology,7:40-57.

Oliveira EJ, Santos VS, Lima DS, Machado MD, Lucena RS, Motta TBN \& Castellen MS (2008) Seleção em progênies de maracujazeiro-amarelo com base em índices multivariados. Pesquisa Agropecuária Brasileira, 43:1543-1549.

Pimentel LD, Stenzel NMC, Cruz CD \& Bruckner CH (2008) Seleção precoce de maracujazeiro pelo uso da correlação entre dados de produção mensal e anual. Pesquisa Agropecuária Brasileira, 43:1303 1309 .

Paiva JR, Alves RE, Melo FIO, Cordeiro ER \& Almeida AS (2002) Genetic progress of selections between and within caribbean cherry open pollination progenies. Crop Breeding and Applied Biotechnology, 2:299-306.

Reis EF, Reis MS, Cruz CD \& Sediyama T (2004) Comparação de procedimentos de seleção para produção de grãos em populações de soja. Ciência Rural, 34:685-692.

Santos CEM, Pissioni LLM, Morgado MAD, Cruz CD \& Bruckner CH (2008) Estratégias de seleção em progênies de maracujazeiro-amarelo quanto ao vigor e incidência de verrugose. Revista Brasileira de Fruticultura, 30:444-449.

Santos CEM, Bruckner CH, Cruz CD, Siqueira DL, Pimentel LD \& Rosado LDS (2010) Repetibilidade em características do fruto do maracujazeiro. Revista Ceres, 57:343-350.

Santos CEM, Bruckner CH, Cruz CD, Siqueira DL \& Rosado LDS (2011) Componentes genéticos aditivos e não aditivos em maracujazeiro-azedo. Pesquisa Agropecuária Brasileira, 46:482-490.

Santos FS, Júnior ATA, Júnior SPF, Rangel RM \& Pereira MG (2007) Predição de ganhos genéticos por índices de seleção na população de milho-pipoca UNB-2U sob seleção recorrente. Bragantia, 66:389-396.

Smith HF (1936) A discriminant function for plant selection Annals Eugenics, 7:240-250.

Suassuna TMF, Bruckner CH, Carvalho CR \& Borém A (2003) Self incompatibility in passionfruit: evidence of gametophyticsporophytic control. Theoretical and Applied Genetics, 106:298-302

Vasconcelos ES, Ferreira RP, Cruz CD, Moreira A, Rassini JB \& Freitas AR (2010) Estimativas de ganho genético por diferentes critérios de seleção em genótipos de alfafa. Revista Ceres, $57: 205-210$.

Vilarinho AA, Viana JMS, Câmara TMM \& Santos JF (2002) Seleção de progênies endogâmicas $\mathrm{S} 1$ e $\mathrm{S} 2$ em um programa de melhoramento intrapopulacional de milho pipoca. Acta Scientiarum, 24:1419-1425.

Vilarinho AA, Viana JMS, Santos JF \& Câmara TMM (2003) Eficiência da seleção de progênies S1 e S2 de milho-pipoca, visando à produção de linhagens. Bragantia, 62:9-17.

Williams JS (1962) The evolution of a selection índex. Biometries, 18:375-393.

Wricke G \& Weber WE (1986) Quantitative genetics and selection in plant breeding. New York, Walter de Gruyter, 406p. 